\title{
Development and Validation of RP-HPLC Method for The Simultaneous Estimation of Amoxicillin Trihydrate and Bromhexine Hydrochloride from Oily Suspension
}

\author{
Lalit V. Sonawane* and Sanjaykumar B. Bari \\ R.C.Patel Institute of Pharmaceutical Education and Research, Near Karwand naka Shirpur, Dist- Dhule, Maharashtra, India
}

\begin{abstract}
A new simple, rapid and precise reverse phase high pressure liquid chromatography (RP-HPLC) method was developed for the simultaneous estimation of amoxicillin trihydrate and bromhexine hydrochloride from oily suspension. An ODS $C_{18}(250 \times 4.5 \mathrm{~mm} \mathrm{ID}), 5 \mu$ particle size with mobile phase methanol and glacial acetic acid $(50: 50 \mathrm{v} / \mathrm{v})$ were used. The flow rate was $1.0 \mathrm{ml} / \mathrm{min}$ and responses were measured at $254 \mathrm{~nm}$. The retention time for amoxicillin trihydrate and bromhexine hydrochloride were observed at 3.04 and $8.18 \mathrm{~min}$. respectively. Linearity for amoxicillin trihydrate and bromhexine hydrochloride were in the range of $8-50 \mathrm{mcg} / \mathrm{ml}$ and $5-25 \mathrm{mcg} / \mathrm{mL}$ respectively. Percent recovery was $99.54 \%$ and $98.65 \%$ for amoxicillin trihydrate and bromhexine hydrochloride respectively. The proposed method can be applied for the routine analysis of amoxicillin trihydrate and bromhexine hydrochloride in combination.
\end{abstract}

Keywords: RP-HPLC; Amoxicillin trihydrate; Bromhexine hydrochloride; Oily suspension

\section{Introduction}

Amoxicillin trihydrate is official in the IP [1], BP [2] and the USP [3], which is 6-(D-4hydroxyphenylglycylamino) penicillanic acid trihydrate chemically. It is generally used as antibacterial whereas bromhexine hydrochloride is official in the IP [1], BP [2] \& USP [3] and used as bronchodilator. The pharmacopoeias describe non-aqueous potentiometric titration methods for the determination of the drugs from bulk drug. No RP-HPLC method is reported for the simultaneous estimation of amoxicillin trihydrate and bromhexine hydrochloride from their combined formulation; though there are various methods for the determination of amoxicillin trihydrate by spectrophotometric $[4,5]$ and bromhexine hydrochloride by spectrophotometric [6,7], simultaneous estimation by HPLC $[8,9]$. The aim of this research work is the development of a simple, rapid and precise RP-HPLC method for the simultaneous estimation of amoxicillin trihydrate and bromhexine hydrochloride from oily suspension.

\section{Material and Methods}

\section{Chemicals}

Oily suspension containing Amoxicillin trihydrate I. P., $125 \mathrm{mg}$ and Bromhexine hydrochloride I.P., $4 \mathrm{mg}$ per $5 \mathrm{ml}$ was procured from the market. Methanol, HPLC grade (Rankem), HPLC grade water, Glacial acetic acid and phosphoric acid AR grade were obtained from $S$.D. Fine chem. Mumbai.

\section{Instrument and conditions}

Chromatographic separation was achieved using High Performance Liquid Chromatograph, JASCO equipped with pump PU 980, universal injector (Rheodyne) with injection volume of 20 mcL, U.V. / Visible detector U.V.975, Borwin software. Intersil $\mathrm{C}_{18}$ Column $(250 \times 4.6 \mathrm{~mm}) 5 \mathrm{mc}$ particle size was used as the stationary phase. SHANUPRO software was used for calculation. The analysis was carried out at room temperature and the flow rate maintained at $1.0 \mathrm{ml} / \mathrm{min}$. The column effluent was monitored at $254 \mathrm{~nm}$.

\section{Mobile phase}

Mobile Phase consisted of Methanol and glacial acetic acid $(1 \% \mathrm{w} / \mathrm{w})$ in the proportion of 50:50 was prepared and $\mathrm{pH}$ adjusted to 3.0 with phosphoric acid. Mobile phase was filtered through $0.45 \mathrm{mc}$ membrane filter and degassed. a) Preparation of Standard Solutio100mg of amoxicillin trihydrate was accurately weighed, transferred in $100 \mathrm{~mL}$ volumetric flask and $25 \mathrm{~mL}$ of mobile phase was added, sonicated for $15 \mathrm{~min}$. and diluted up to mark with mobile phase.

b) $100 \mathrm{mg}$ of bromhexine hydrochloride was accurately weighed, transferred in $100 \mathrm{~mL}$ volumetric flask and $25 \mathrm{~mL}$ of mobile phase was added, sonicated for $15 \mathrm{~min}$. and diluted up to mark with mobile phase.

\section{Preparation of working standard}

$25 \mathrm{~mL}$ of solution (a) and $0.8 \mathrm{~mL}$ of solution (b) were taken in $50 \mathrm{~mL}$ volumetric flask and mixed well. The volume was made up to the mark with mobile phase to get the concentration of $25 \mathrm{mg}$ / $\mathrm{mL}$ and $0.016 \mathrm{mg} / \mathrm{mL}$ of Amoxicillin trihydrate I. P and Bromhexine hydrochloride I.P. respectively. The resultant solution was filtered through $0.2 \mathrm{mc}$ membrane filter paper.

\section{Preparation of sample solution}

Accurately measured $5 \mathrm{~mL}$ of oily suspension (uniformly dispersed) was taken in $100 \mathrm{~mL}$ separating funnel. The content of oily suspension was extracted with $2 \times 25 \mathrm{~mL}$ of mobile phase. The aqueous part was transferred to $250 \mathrm{~mL}$ volumetric flask and volume was made up to mark with mobile phase. The resultant solution was filtered through $0.2 \mathrm{mc}$ membrane filter paper.

\section{Assay}

The working standard solution and sample solution were injected $(20 \mathrm{mc})$ through Rheodyne injector of liquid chromatograph and

*Corresponding author: Lalit V. Sonawane R.C.Patel Institute of Pharmaceutical Education and Research, Near Karwand naka Shirpur, Dist- Dhule, Maharashtra India 425405, E-mail: lal303@rediffmail.com

Received August 30, 2010; Accepted September 27, 2010 Published September 30, 2010

Citation: Sonawane LV, Bari SB (2010) Development and Validation of RPHPLC Method for The Simultaneous Estimation of Amoxicillin Trihydrate and Bromhexine Hydrochloride from Oily Suspension. Pharm Anal Acta 1:107. doi:10.4172/2153-2435.1000107

Copyright: ( 2010 Sonawane LV, et al. This is an open-access article distributed under the terms of the Creative Commons Attribution License, which permits unrestricted use, distribution, and reproduction in any medium, provided the original author and source are credited. 
Citation: Sonawane LV, Bari SB (2010) Development and Validation of RP-HPLC Method for The Simultaneous Estimation of Amoxicillin Trihydrate and Bromhexine Hydrochloride from Oily Suspension. Pharm Anal Acta 1:107. doi:10.4172/2153-2435.1000107

Page 2 of 6

peaks were recorded. The amount of drug samples were calculated from the peak area (response factor) obtained.

\section{Recovery}

The analytical recovery of amoxicillin trihydrate and bromhexine hydrochloride was determined at concentrations of 100,150 and $200 \mathrm{mcg} / \mathrm{mL}$. The test solution was spiked with known amounts of the drug to achieve the concentration previously specified. These samples were processed by the analytical method described above and peak heights were compared with the peak heights obtained by direct injection of the drugs in the mobile phase. The linearity study was carried out in the range of 50 to $250 \mathrm{mcg} / \mathrm{mL}$ and 25 to $200 \mathrm{mcg} /$ $\mathrm{mL}$.

\section{Validation of method}

As per $\mathrm{ICH}$ [10] guideline the method is validated and following parameters were evaluated.

\section{Accuracy}

Accuracy of the method was checked by assaying the samples using analyte recovery method. These samples were processed by the analytical method described above and peak areas were compared with the peak areas obtained by direct injection of the drugs in the mobile phase. The analytical recovery of amoxicillin trihydrate and bromhexine hydrochloride was determined at concentrations of 100,150 and $200 \mathrm{mcg} / \mathrm{mL}$

\section{Precision}

Precision of the method was studied by analysis of multiple samplings of homogeneous sample and expressed as CV. It was demonstrated by intra-day and inter-day variation studies.

\section{Ruggedness and robustness}

Ruggedness of the method was determined by carrying out the experiment of different instruments by different analyst and on different days, showed that the method was rugged. Robustness of the method was determined by making slight changes in chromatographic conditions.

\section{Result and Discussion}

\section{Optimization of chromatographic method}

The mobile phase composing methanol and glacial acetic acid $(1 \% \mathrm{w} / \mathrm{w})$ in the proportion of 50:50 was prepared and $\mathrm{pH}$ adjusted

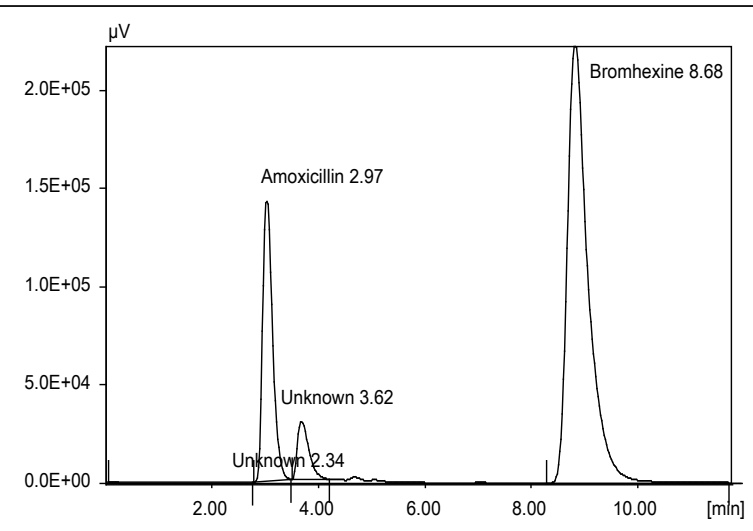

Figure 1: Typical Chromatogram of Test Sample Peak Amoxicillin - Amoxicillin trihydrate $\left(\mathrm{t}_{\mathrm{r}}=2.97\right.$ mins) Peak Bromhexine - Bromhexine hydrochloride $\left(\mathrm{t}_{\mathrm{r}}=\right.$ 8.68 mins).

\begin{tabular}{|l|l|c|c|c|c|c|}
\hline Formulation & Label Claim(mg) & $\begin{array}{c}\% \text { of } \\
\text { Amoxicillin } \\
\text { trihydrate }\end{array}$ & CV & \multicolumn{2}{|c|}{$\begin{array}{c}\% \text { of } \\
\text { Bromhexine } \\
\text { hydrochloride }\end{array}$} & CV \\
\hline & $\begin{array}{l}\text { Amoxicillin } \\
\text { trihydrate }\end{array}$ & $\begin{array}{l}\text { Bromhexine } \\
\text { hydrochloride }\end{array}$ & & \multicolumn{2}{|c|}{} & \\
\hline $\begin{array}{l}\text { Oily } \\
\text { suspension }\end{array}$ & 125 & 4 & 100.24 & 0.64 & 99.41 & 0.85 \\
\hline
\end{tabular}

CV- Coefficient of variation

Table 1: Results of HPLC assay.

\begin{tabular}{|c|c|c|c|c|c|c|}
\hline \multirow{2}{*}{$\begin{array}{c}\text { Sr. } \\
\text { No. }\end{array}$} & \multicolumn{2}{|c|}{$\begin{array}{c}\text { Conc. of added drug } \\
\text { in Pre analyzed } \\
\text { formulation mcg/mL }\end{array}$} & \multicolumn{2}{|c|}{$\begin{array}{c}\text { Recovery of added drug } \\
\mathrm{mcg} / \mathrm{mL}\end{array}$} & \multicolumn{2}{c|}{$\%$ Recovery } \\
\cline { 2 - 7 } & $\begin{array}{c}\text { Amox. } \\
\text { trihydrate }\end{array}$ & $\begin{array}{c}\text { Bromhexine } \\
\mathrm{Hcl}\end{array}$ & $\begin{array}{c}\text { Amox. } \\
\text { trihydrate }\end{array}$ & $\begin{array}{c}\text { Bromhexine } \\
\mathrm{Hcl}\end{array}$ & $\begin{array}{c}\text { Amox. } \\
\text { trihydrate }\end{array}$ & $\begin{array}{c}\text { Bromhexine } \\
\mathrm{Hcl}\end{array}$ \\
\hline 1. & 5 & 5 & 5.03 & 4.99 & 100.52 & 99.80 \\
\hline 2. & 10 & 10 & 9.87 & 9.75 & 98.69 & 97.50 \\
\hline 3. & 15 & 15 & 14.72 & 14.82 & 98.14 & 98.80 \\
\hline
\end{tabular}

Table 2: Results of recovery study.

\begin{tabular}{|c|c|c|c|}
\hline $\begin{array}{c}\text { Sr. } \\
\text { No. }\end{array}$ & Parameter & $\begin{array}{c}\text { Amox. } \\
\text { trihydrate }\end{array}$ & $\begin{array}{c}\text { Bromhexine } \\
\mathrm{Hcl}\end{array}$ \\
\hline 1 & Capacity Factor $\left(\mathrm{K}^{\prime}\right)$ & 674.25 & 984.5 \\
\hline 2 & Resolution $(\mathrm{Rs})$ & 8.39 & 11.14 \\
\hline 3 & Tailing Factor $(\mathrm{T})$ & 1.58 & 1.79 \\
\hline 4 & Theoretical Plate(N) & 3646.35 & 4281.51 \\
\hline 5 & Calibration Range $(\mathrm{mcg} / \mathrm{ml})$ & $50-250$ & $50-200$ \\
\hline 6. & $\%$ RSD & 1.7349 & 1.6542 \\
\hline
\end{tabular}

Table 3: System suitability parameters.

to 3.0 with phosphoric acid showed good resolution peaks within a short run time. The typical chromatograph is shown in Figure 1.

\section{Linearity}

The amoxicillin trihydrate shows the linearity in the range of 50 to $250 \mathrm{mc} / \mathrm{mL}$ and bromhexine hydrochloride $25-200 \mathrm{mc} / \mathrm{mL}$. an excellent correlation was observed in the peak area and the concentration of amoxicillin trihydrate and bromhexine hydrochloride.

\section{Assay and recovery}

The Table 1 shows assay results which indicate that method is precise and accurate. The results of recovery study given in Table 2 confirm the accuracy of the method. The proposed RP-HPLC method is accurate, simple, rapid and selective for the simultaneous estimation of amoxicillin trihydrate and bromhexine hydrochloride in oily suspension form. Hence it can be conveniently adopted for the routine quality control analysis of the oily suspension.

\section{Validation of Method}

As per the current regulatory requirements, the validation of the developed method was carried out by studying different system suitability parameters, respectively for amoxicillin trihydrate and bromhexine hydrochloride were: resolution, tailing factor, theoretical plates, \% RSD and capacity factor. Resolution between the two components should be more than 3.0, tailing factor should be less than 2 and theoretical plates should be more than 2000. It is evident from table 3 that method developed for these two drugs in combination is passing the standards of regulatory requirements.

\section{Conclusion}

The newly developed method for the simultaneous estimation of amoxicillin trihydrate and bromhexine hydrochloride was found to be precise and accurate with low values of coefficient of variation. Hence it can be conveniently adopted for the routine quality control analysis of the oily suspension. 
Citation: Sonawane LV, Bari SB (2010) Development and Validation of RP-HPLC Method for The Simultaneous Estimation of Amoxicillin Trihydrate and Bromhexine Hydrochloride from Oily Suspension. Pharm Anal Acta 1:107. doi:10.4172/2153-2435.1000107

Page 3 of 6

\section{Acknowledgement}

Authors are grateful to Dr. Kuchekar B.S. for providing SHANUPRO software used for calculation.

\section{References}

1. Indian Pharmacopoeia (1996) Volume I, 50,111.

2. British Pharmacopoeia (1993) Volume I, 43, 100.

3. The United States Pharmacopoeia XXIII/ NF 18, 1995, 100, 129.

4. Ellaithy MM, El-Bardicy MGM, Ibrahim W (1986) Stability indicating method for the analysis of some acid stable penicillins. J Assoc Off Anal Chem 69: $173-177$

5. Dave JB, Banerjee SK (1986) Spectrophotometric estimation of amoxycillin by reaction with diazotized primary aromatic amines. Indian Journal of Pharmaceutical Sciences 48: 73-75.

6. Trivedi P, Gangwal S (1999) Simultaneous determination of terbutaline sulphate, bromhexine hydrochloride and guaiphenesin in three-component tablet formulation by UV spectrophotometry. Indian Jounal of Pharmaceutical Sciences 61: 128-130.

7. Rathore YKS, Murugesan N, Mathur SC, Kumar Y, Sethi PD (1992) Simultaneous spectrophotometric determination of salbutamol sulphate and bromhexine hydrochloride in tablets. Indian Journal of Pharmaceutical Sciences 54: 206-208.

8. Bhounsule GJ, Gorule VS (1993) Simultaneous determination of pseudoephdrine hydrochloride,chlorpheniramine aleate, and bromohexine hydrochloride in liquid preparation (of cough decongestants) by HPLC. Indian Drugs 30: 258-263.

9. Sane RT, Gangal DP, Tendolkar RV, Kothurkar RM, Ladge KD, Joshi Leela (1990) Simutaneous HPLC chromatographic determination of bromohexine hydrochloride and salbutamol sulphate from pharmaceutical preparation. Indian Journal of Pharmaceutical Sciences 52: 197-199.

10. Text on validation of analytical procedures, $\mathrm{ICH}$ Harmonized tripartite guidelines, adoption of $27^{\text {th }}$ Oct.1994. 